\title{
Syndicate Marriage or Trafficking? The Travails of Asian Migrant Women
}

\author{
Muhamad Helmi Md Said ${ }^{*}$ \\ Grace Emmanuel Kaka' \\ Muhammad Amrullah Bin Drs Nasrul ${ }^{2}$ \\ Tinuk Dwi Cahyani3 \\ ${ }^{1}$ Faculty of Law, Universiti Kebangsaan Malaysia (UKM), \\ 4360o, Bandar Baru Bangi, Selangor, Malaysia \\ ${ }^{2}$ Ahmad Ibrahim Kulliyah of Laws, International Islamic University of Malaysia, \\ 5310o, Gombak Selangor, Malaysia \\ ${ }^{3}$ Fakultas Hukum, Universitas Muhammadiyah Malang, \\ Jalan Raya Tlogomas No.246 Malang, Indonesia \\ ${ }^{*}$ Corresponding author
}

DOI: https://doi.org/10.36941/jesr-2022-0o1o

\section{Abstract}

Migration is a phenomenon that has come to stay. It cuts across all nations in the world. People migrate for different purposes such as education, marriage, labour, job opportunity or employment and shelter for refugees. Migration occurs through various mediums which could be self, family members, friends, or other intermediaries such as brokers. This research applied the pure library-based research method to highlight the activities of brokers in migration in Asia and examine the ordeals of women victims in cross-border migration. It was discovered that activities of these illegal brokers, that is also known as syndicates, are not different from human trafficking. The women victims, whose desires are to change their status, soon got trapped in uncertainty with shattered dreams, hence the suggestion that Asian countries enter into bilateral agreement to enable favourable and a less strict migration procedures for their member states. In addition, the contracting states should enact strict legislation to curb syndicate marriage and check the accesses of these illegal brokers.

Key words: migration, illegal brokers, syndicate marriages, cross-border marriages, trafficking

\section{Introduction}

Studies show an increasing number of women from under-developed South-Asia have migrated to the more developed Asian countries to upgrade their status and relieve their family from poverty through cross-border marriages. Cross-border marriage is thus a form of migration strategy for economic gain and a source of family support (Tsay. 2004; Constable, 2005). These women's interest has been found to align itself with some government policies towards attracting cross-border marriages to salvage falling birth rate (Wang \& Xiao, 2009; William, 2010). It has been argued that 
migration sometimes attracts potential spouses overseas with high level of education (Celikaksoy, Nielsen \& Verner, 2006; Hamel et al., 2012; Ersanilli \& Charsely, 2019), though to less educated men (Charsley, 2013). Yet, when the marriage is closely considered, it is more of a sham, a syndicate arrangement than a realistic marriage that meant to last between the couples. This is because most of these marriages end up in divorce or separation on either mutual grounds, or fraud, or due to abuse or domestic violence (Kim et al., 2017; Kapur \& Zajicek, 2018; Smith, 2019; Choi, Kim \& Ryu, 2019). In this study, syndicate means illegal brokers and shall be used interchangeably to describe each other. Since mid-200o, border crossing has been reinforced and bribing border guards to smuggle in has become to some extent, impossible. Hence cross-border crossing became difficult with border restrictions (Abdallah, 2021), making others to seek alternatives by hiring smugglers or brokers to assist them in migrating. Most of these smugglers are foreigners who themselves were smuggled in and well versed with the system. However, they have chosen to use such experiences to turn themselves into brokers for interested persons seeking their assistance. It was found that some victims present themselves willingly to be trafficked so that they can migrate (Kook, 2018). Wide age gap between the couples is apparent in this type of marriage migration, all in a bid for the vulnerable women migrant to acquire legal status in destination country and for profit for the brokers (Guetto and Azzolini, 2015; Elwert, 2016; Balistreri et al., 2017).

Syndicate marriage is the type of marriage conducted by certain individuals who do not have the authority to solemnize the marriage in accordance with the law. These marriages are usually held in secret, away from parents and guardians whose consent are required to validate the same (Saidon et al., 2015). The couples are then issued with fake marriage certificates as evidence of the marriage. These syndicate arrangements have different facets, either contracting a marriage between two locals, or a local and a foreigner or between two foreigners in a foreign country or destination country. However, the scope of this research is syndicate marriage in cross-border migration. Examination of ordeals of the children from this arrangement or that of the male spouse is outside the scope of this research as the study is restricted to the ordeals of the female victims alone. In doing so, the researchers reviewed literature, discussed the methodology, activities of both formal and informal brokers, ordeals of women victims, legal implications of sham marriages conducted by the brokers and offered some recommendations and conclusion.

\section{Literature Review}

\subsection{Migration}

Migration involves movement of people from one place to the other, usually attributed to crossingborder marriages. It may be long-term or short-term (King, 2012) and the idea behind migration is for permanent or temporary settlement depending on the purpose of migration (Skeldon, 2015). Migration occurs through various means which could be family, friends, self, or other intermediaries. These migration intermediaries (Eerbeek, 2019) include: migration industries (Salt \& Stein, 1997; Gammeltoft Hansen \& Nyberg Sorensen, 2013; Cranston et al., 2018), migration infrastructures (Xiang \& Lindquist, 2014; Lin et al., 2017) and migration brokers (Lindquist, 2012; Lindquist et al., 2012; Mckeown, 2012; Cranston et al., 2018). However, the relationship between these terminologies used for migration intermediaries are that migration is an increasingly mediated process. In migration, many non-state actors are involved in the process such as brokers, illegal smugglers, family members, spouses, non-governmental organizations (NGOs), security firms and labour recruiters (Faist, 2014). Due to neoliberalism and new public management, states have decentralized a greater part of migration process to private organizations such as border control, migration detention, selection procedure, and visa application process. Finally, cheap migrant labour demand by employers led to temporary work scheme and circular migration (Eerbeek, 2019) in recent times.

Previous studies on cross-border marriages have either discussed on the difficulties of crossborder couples to obtain citizenship in the process of migration or barriers to integration and the like 
(Constable, 2005; William, 2010). While others discussed on domestic violence and abuse faced by these cross-border wives (Kim et al., 2017; Kapur \& Zajicek, 2018), some other studies have also addressed on activities of agencies in the migration process (Kyunghee, 2019) as well as the activities of NGO's and other social groups in helping out migrants to adapt in their destination countries (Smith, 2019; Choi, Kim \& Ryu, 2019). Yet studies on the ordeals of these immigrants that were either exploited or willingly taken to destination countries illegally by syndicates are lacking. The lack of studies has sparked interests to initiate this research to highlight the activities of syndicates and examine the ordeals of women victims. The study seeks to expose the hidden truth about this type of migration and reveal that they are the same with human trafficking, hence the need for urgent action by states at both local and international level to curb the menace. This is because most of the studies on illegal immigrants and the activities of syndicate have been on human trafficking (Ichuygu \& Toktas, 2002) while cross-border marriages arranged by illegal brokers or brokerage industries are less discussed as they are rarely considered a problem in the migration process. It is also due to some states subletting their powers of border control, visa process and the likes to private organizations (Eerbeek, 2017). Unfortunately, when the entire process of these illegal migration by illegal brokerage is considered, it is no different from human trafficking because the consequence in the destination countries is somewhat similar.

\subsection{Brokerage (Brokers)}

The growing rate of cross-border marriages led to marriage brokers and matchmaking agencies to thrive recently. Brokers play a vital role in the process of migration. Stovel and Shaw (2012 p. 141) define brokerage as "the process of connecting actors in systems of social, economic, or political relations in order to facilitate access to valued resources." These resources may be material or immaterial. This brokerage can facilitate social, political, and economic interactions and progress while at the same time worsen social inequalities through exploitation, abuse of power, pursuit of personal gains and corruption. Brokerage can involve the process of entry, settling down and other needs for migrants in destination country. Brokerage could be for labour migration (Abella, 2004; Kuptsch, 2006; Rodriguez, 2010; Martin, 2017), education migration (Thieme, 2017; Robinson-Pant \& Magyar, 2018) and marriage migration (Constable, 2012; Chee, 2012; Belanger, 2016). Overall, brokerage can be formal or informal, legal or illegal. Many cross-border couples have been brought together by kingship and social networks as well as marriage brokers (Yang \& Lu, 2010). A growing number of marriages have been facilitated by agencies called brokers (Schaeffer, 2013) and these international marriage brokers are accessed by individuals via internet, newspaper advertisement, traditional mail correspondence, or organized "matchmaking" tours (Constable 2003; Lu 2008). In brokerage for marriage, the broker in destination country will recruit men and the broker in source country will recruit women migrants. They will contact each other and provide avenues for both parties to meet and choose. This is usually done through a short visit (Kawaguchi \& Lee, 2016). These brokers are said to serve as avenues for individuals to locate their match (Balistreri et al., 2017). However, this research will restrict itself to illegal migration by brokerage in marriage migration.

Illegal migration or elicit smuggling has been argued to be due to tightening legal migration channels by receiving-countries (Abubaker, 2018). As such the only way potential migrants can enter other countries is through illegal border crossing usually with the help of third parties - brokers (Graycar, 2000; Salt, 2000; Ichuygu \& Toktas, 2002). Illegal or elicit smuggling should not be mistaken as human trafficking even though both have to do with transportation of people from one place to another. This is because, while human trafficking is regarded as transportation of persons for purposes of exploitation, coercion, deception, or other illicit influence (Salt, 2000; Shelley, 2001; Tailby, 2001), human smuggling is associated more with illegal border crossing under the assistance of third parties - often brokers (Skeldon, 2000; Salt 2000; Shelley, 2001).

Syndicates like human traffickers are prone to committing human rights violations such as rape, physical and mental abuse, starvation, abandonment and even death (IOM, 200o; Ibrahim, 2018). All 
in a bid for brokers to make profit and secure migration for immigrant victims. Hence the words of Freeman (2011, p. 87) that cross-border marriage between South Korean and Korean Chinese brides from China is dominated by international marriage brokers operating a mixture of registered and unregistered matchmaking agencies mainly for profits. Indeed, such profits have been criticized to be a form of commercialization and commodification. It has been further argued that the process is not different from trafficking for sexual exploitation because the brokers catalogues are browsed to pick the choice bride, and a visit for final arrangement within a few days (Hughes, 2000; 2004). This is because potential men see these wives as commodities they purchase thereby rendering the brides, victims of sexual exploitation (Ibrahim, 2018; Kyunghee, 2019).

Illegal brokers are now often visualized as a global business consisting a well-organized criminal, mafia-type formation involving countries of origin, transit, and destination countries. Their businesses thrive due to excessive demands of illegal entry challenges because of increasingly stringent entry controls and near impossibility of regular migration (Ichuygu \& Toktas, 2002). However recently business has not been as good as it was because informal brokerage has taken over with well covered tracks from being caught (Abubaker, 2018; Ibrahim, 2018; Abdallah, 2021).

Authors have asserted that some legislations have been the reason behind the stereotype towards brokers and victims of cross-border marriages. For instance, it was argued that the International Marriage Broker Regulation Act in the United States, oversimplified migrant women as potential victims of trafficking and justified anti-immigration legislations (Constable, 2012). These brokers form a large chain of agents who play different roles in the migration process, from matchmaking, to marriage registration, visa processing and settling down or integration in destination countries (Wang \& Chang, 2009; Haisel, 2018).

\section{Methodology}

The library-based research method was employed to highlight the activities of brokers in crossborder marriage migration and examine the ordeals of women victims in this migration pattern. The study found that there are formal and informal brokers in addition to the legal and illegal brokers. Nonetheless most of the activities of this syndicate, the illegal brokers to which this study is interested in, violate human rights. The violation exists because their activities are not different from human trafficking. The only difference is in the nomenclature and the fact that while human trafficking is internationally recognized as a criminal offence with sanctions, syndicate marriages are not. They are not considered a criminal offence and the fact that some countries have sublet their powers of border control to private organizations (Eerbeek, 2017).

\subsection{Activities of brokers}

\subsubsection{Formal brokers}

Brokers contribute to settlements of escapees and formal brokers offer job opportunities especially in the domestic sphere to avoid surveillance from immigration authorities (Kyunghee, 2019). A broker has been argued not to be a fixed identity and must be considered in relation to power, time, location, and opportunity (Lundquist, Xiang and Yeoh, 2012). Brokerage consists of complex procedures of matchmaking, risk management (Luhmann, 1993; McKeown, 2012), negotiation of emotions and power between intending couples (Yeoh et al., 2017). Although from the process of the brokerage, especially the screening procedures intending brides go through such as body shape, age, educational qualification, skin colour, virginity test and health fitness, one would no doubt see discrimination in the entire process as their men counter parts do not undergo such procedures, yet the men are the ones eligible to buy these intending brides (Yeoh et al., 2017). These women are presented like commodities and though sometimes the procedures are genuine, the outcome of the futures of these migrant brides remains uncertain. These brokers have been found to make fake 
identity document (ID) cards, fake marriage certificates, fake passports of country of origin or destination country, which greatly help migrants when moving out of destination country by ship or air (Alexander, 1997). The relationship between women migrants and brokers compared to their male counter parts were found to be different (Kyunghee, 2019). The difference is apparent because women are dependent on the brokers not only for migration but also for job opportunities and suitors for marriage purposes where those jobs are unavailable (Kyunghee, 2019). As such these brokers tend to find wide range connections amongst family members, religious leaders, and the locals who in turn are greatly involved in the brokerage (Kyunghee, 2019). For instance, it was observed that in Chinese Korean cross-border experiences, these women stay for a long time in the houses of the brokers until their opportunities set in. This depicts an informal arrangement. Thus, being an informal arrangement, besides being a lucrative criminal machine, job and marriage arrangements are also informal and most times sham (Kyunghee, 2019). Most of the marriages are usually on paper for the immigrant wives to prolong her stay in the destination country and sometimes used as avenues to obtain citizenship where the laws of the destination country are liberal (Ibrahim, 2018; Abubaker, 2018). A recent study linked these sham marriages by illegal syndicates to human trafficking (Luong, 2020). In Asia, it was found that most of the human trafficking activities have international brokers involved in foreign countries such as Thailand, Malaysia, Indonesia, Singapore (MPS, 2018, Abubaker, 2018; Said et al, 2019). It is worth to note that their victims are majorly women and children from Vietnam, Bangladesh, Philippines. These women are lured into "marriages" through the "mail order brides" process (Hwang \& Parrenas, 2018) or offered lucrative job with high payment but it was rather unfortunate that they are later forced into prostitution or forced labour or domestic servitude (Phuong, 2015; Nhien, 2016; Hoang et al., 2018, Ibrahim, 2018). In Malaysia for instance, it was discovered that these illegal brokers contract syndicate marriages which are not in compliance with the requirements of a valid marriage either in the source country or in Malaysia the country of destination (Abdallah, 2021; Hak et al, 2017). Malaysia being a Muslim country, marriages for Muslims are guided by the Holy Quran and must be in line with the Islamic Family Law legislations of the various states (Said et al, 2019). The states' enactment requires the consent of the Wali or known as legal guardian to conclude a valid marriage (Jamaluddin, 2021). It was also found that sometimes the difficulty of getting consent of the Wali has led many into sham marriages through the hands of illegal brokers (Salidon et al., 2015) which the government now is making efforts to investigate and prosecute (Abubaker, 2018; Abdallah, 2021). In a recent research, it was discovered that most of the brokers seem sincere and honest at the initial stage, an act that infiltered the trust of the victims. Regrettably, the brokers then sell these women for prostitution or to marriage brokers who arrange for forced marriages instead of getting them a job (Ibrahim, 2018). The sham marriages have been found to be a barrier to border control measures (Wemyss et al., 2018). These marriages have legal implications not only on the couples involved, but also the religious bodies and marriage registries that contract them. While trying to run away from surveillance, these cross-border wives had to remain in those marriages and endure all sorts of domestic violence and inhuman treatment because there is no place of escape (Smith, 2019). Also, due to language barriers, they are unable to spot bad omen in the discussions between their host brokers and their transferred brokers. As such, only a few have been able to escape from the marriage brokers in fierce situations (Kyunghee, 2019).

Research found that there are times when the prospective foreign husbands had been tricked into paying hundreds of dollars to dishonest brokers as registration cost, initial fees, consultation, preliminary and the likes yet all they got were unsuccessful marriage arrangements. These men are unable to complain because complaining would mean admission of crime to defraud the immigration department (Mackellar, 2008). In Australia, it was argued that a woman's long stay in a marriage is not a guarantee because immediately after she obtains permanent residency, she abandons the marriage (Mackellar, 2008). These brokers' arrangements are risky due to mismatched expectations, hidden spousal flaws, failure to obtain valid documents, family clash with in-laws caused by language and culture barriers and divorce or separation (Constable, 2005; Yeoh et al., 2017). There is also the fear of the marriage being a sham or marriage of convenience for exploitation purposes of obtaining 
citizenship by one partner.

\subsection{Informal brokers}

\subsubsection{NGOs and Social networks}

Some NGOs and social networks assist migrants to migrate to better developed countries or countries with liberal government as a source of freedom. This is the case of North Korean NGOs who assist the North Koreans to escape from North Korea and China to South Korea, a more liberal country (Kyunghee, 2019). Some of the escapees explained that their lives are being threatened as they are treated as saboteurs. The NGOs also assist migrant women going through domestic violence and help them escape by providing various services from counselling to language teaching, pro bono legal services and shelter homes (Kapur, Zajicek \& Gaber, 2015).

\subsubsection{Family members}

Sham marriages overseas are sometimes carried out by close family members. Usually with the consent of the migrant women involved. A research in Australia revealed that marriages leading to genuine Australian Permanent Residency (PR) are mostly sham marriages. In the case of Indonesians, the process is "brother/sister" marriage but for the Indians, it is the use of the "Indian rope trick" and in all these cases, they are never detected (Mackellar, 2008). In the Philippines, there exists the concept of "the mail ordered brides". These sham marriages have been found to be a significant source of chain migration for migrants and a burden to receiving countries innocently. As such, one would no doubt agree that there is a thin line between legal and illegal status. It is a matter of time for the legal status to transform into illegal and vice versa.

\subsubsection{Places of worship (church or mosque)}

Places of worship like churches, mosque and temples have been found to be informal brokers for migrant women. These places of worship do not only serve in aiding to the migrant women in crossborder marriages but also facilitating their marriages to locals as a way of protecting and safeguarding their interest in the destination countries (Kyunghee, 2019). This is because most of these women come in either as illegal migrants through illegal brokers, in which case they do not have shelters, or as cross-border wives who possess no valid or legal documents to secure their stay in the destination countries. It was found that in order to make their work effective on immigrant women, some NGOs had joint efforts with religious bodies to help immigrant women out of their unfortunate experiences (Kapur, Zajicek \& Gaber, 2015).

\subsubsection{Shop owners (Grocery sellers)}

A study of Korean Chinese migrants proved that the network of brokerage, also include shop owners or groceries sellers. They are included because some of the respondents who had become helpless, hungry and at the verge of giving up life for starvation, were assisted by grocery shop owners, who did not only offer them food but transferred them to other brokers (Kyunghee, 2019).

\subsubsection{Drivers in transport systems}

It was found in China that even drivers and motorcyclist are involved in brokerage from the words of some of the respondents in a research on the Korea-China migration (Kyunghee, 2019). 


\subsubsection{Head of villages}

Village heads and leaders of various areas have been found to be mafias in brokerage. In Asia, they have been discovered to be highly involved in selling migrant women to interested husbands as commodities thereby fueling the ordeals of these migrant women through domestic violence (Kyunghee, 2019, Smith, 2018).

\subsection{Ordeals of women MIGRANTS}

\subsubsection{Selling and reselling}

The migrant women are sold and resold by illegal brokers to fellow illegal or mafia brokers from the point of entry to destination countries. Even in the destination countries, their lives are not easy as these brokers continue to sell and resell the women once they no longer need them or enter into syndicate marriages or struggle to obtain valid documents on their own (Kyunghee, 2019).

\subsubsection{Forced and/or illegal marriage arrangements}

Migrants women life experiences in an empirical research, revealed that most of them are forced into syndicate marriages (Kyunghee, 2019). Only a few willingly enter into these marriages (Eerbeek, 2017) for shelter, food and life necessities or prolonging their stay in the destination country so as to get employed in the process and assist their relatives back in their country of origin.

\subsubsection{Prostitution}

Just like human traffickers' traffic for sexual exploitations, those whom the illegal smugglers assisted to cross-borders but refused these syndicate marriages, are forced into prostitution for profit. It is plausible because mostly from the time they arrive the destination countries, they are kept in the houses of these brokers for weeks or even years before they finally get linked (Kyunghee, 2019).

\subsubsection{Starvation}

Research shown that most migrants that were smuggled in by illegal brokers and who have decided to make a better life or break free from the syndicates, experience starvation to death in some instances. These women are foreigners on a strange land, having nowhere to go and no one to turn to, they mostly stay on the streets and in the mountains, starving and running away from surveillance to avoid deportation (Kyunghee, 2019).

\subsubsection{Homelessness or always on the move}

Domestic violence (Mayock \& Sheridan, 2012; Bretherton \& Pleace, 2018), sexual victimization (Kay et al., 2019; Haile et al., 2020), poverty, violence in the community, loss of employment, loss of access to affordable housing, eviction, mental illness, drug abuse, history of childhood violence are causes of homelessness and unsafe spaces (Levin et al., 2004; Thomas, 2009; Duchesne, 2015; Andrade, 2018; Tracy, 2019). A study in Ethiopia found that factors of homelessness include migration, urbanization, abuse, escape from child and forced marriage, death, divorce or separation, abandonment, pregnancy outside wedlock and poor educational status (Edwards et al., 2015; Nathan \& Fratkin, 2018; Ali, 2012; 2014). It was found that some of these migrant women become homeless in the process of breaking away from the brokers that smuggle them into destination countries. As such, some respondents in a recent study by Kyunghee (2019), said they are constantly on the move, running from one mountain to the other and hiding both from their illegal brokers and surveillance of immigration officers. 


\subsubsection{Uncertainty of life}

Migration experience generally has negative impacts on the marital prospects of unmarried women (Nisrane et al., 2020; Ullah, 2013). Migration also affects immigrants' integration into destination countries (Belanger \& Rahman, 2013; Nisrane et al., 2020). In addition, research have shown that the psychological trauma of sexual violence experienced by women during migration, among the married or unmarried, affects reintegration in their country of origin (Ketema, 2014). There is no certainty as to whether they ever get jobs or are comfortable enough to discharge their duties as dutiful daughter (Straiton et al., 2019). As such, there is uncertainty for these migrant women in every area of their lives once they begin the migration journey.

\subsubsection{Domestic violence}

It was argued that violation of gender norms due to women's migration experiences and threatened masculinity leads to conflict and domestic violence (Kifkeyesus, 2012). It was further found that the broker's one way recruitment, financial powers of the will-be-husbands, the desire of the immigrant women to escape their poverty state in their country of origin, their illegal status and uncertainties about their lives render them vulnerable to abuse (Chun, 1996, Smith, 2019) and domestic violence. These immigrant women are both unable to report or escape domestic violence due to lack of money and their illegal status. As such, women continue to endure all sorts of maltreatment and inhuman treatments from both, their arranged husbands and the brokers to whom they would turn to for help (Yu \& Chen, 2018).

\subsubsection{Legal implications of syndicate marriages}

Sham marriages conducted by syndicate are mostly invalid. They do not find validity in both the country of origin and the destination country because these marriages are not conducted in accordance with the legal requirements of a valid marriage in either countries. As such, those women become victims of illegal paper marriage. A recent investigation in Malaysia revealed that these women are brought into the country for prostitution and when arrested, elderly Malaysian men will come to bail them out as their wives and even present marriage certificates to that effect (Ibrahim, 2018). Also, some of the marriages contracted by informal brokers such as "Indian rope stick", "double banger" and "mail-ordered" brides also come with complications that affects the validity of an already existing marriage (Mackellar, 2008). For instance in the case of "the Indian rope stick", an extended family member who already obtained his PR status, marry member of the extended family for the purpose of migrating every member of the family, and in the process it was found that some cut the chain soon after they fall in love with each other or have a child together during the two years waiting period before the PR and subsequent divorce (Mackellar, 2008). Their parents and other family members had to call the Australian Immigration to deport them for each to come back to their respective spouses and children. It can never happen because they were already legally married in Australia and now have a valid status with a PR. As such, India cannot prosecute them for an offence under affinity and consanguinity in Australia. The "double banger" is a situation where couples desiring to migrate, each marry a citizen of the destination country and they maintain three (3) marriages pending citizenship or PR status. Soon after obtaining citizenship or the PR status, they divorce their respective foreign partners and marry each other again in the destination country. They often hide their identities, hence detecting them becomes nearly impossible (Mackellar, 2008; Abubakar, 2018). Sometimes, one of the spouses of the first marriage soon find out that they prefer their foreign partner and refuse to go for divorce after obtaining citizenship. In such situations, the marriage in the destination country is valid so as the first marriage in the country of origin. However, the other spouse cannot sue for bigamy in the destination country as there is no record or evidence to prove that. Also, a recent investigation in Malaysia shows that these syndicates issue fake certificates 
to the couples which is neither legally acceptable in Thailand nor in accordance with the Malaysian Islamic family law Malaysia (Ibrahim, 2018; Abdallah, 2021). These syndicates have been argued to create complications in marriages by enabling those not eligible to engage in polygamy to do so in Malaysia (Saidon et al., 2015). It is this invalidity that further exacerbates the women's uncertainty in the destination countries and makes it difficult for them to escape all acts of domestic violence and abuse against them.

\section{Conclusion and Recommendations}

Based on the research conducted, there seems to be a thin line between trafficking and marriages by syndicates because both share similarities in certain aspects of their modus. Indeed the experiences of these women victims in both activities, are the same. These brokers have been found to cause direct and immediate harm to immigrant women involved. Many of them became vulnerable to all manner of abuses and left with uncertainties of life. Brokerage or smuggling promotes sexism, racism and economic subordination which increases abject poverty, breeds bad health conditions and encourages illiteracy. Thus, truncating and making it near impossible for the worlds pursuit of sustainable development goals (SDG) by 2030.

There is a need for enactment of legislations to protect the interest of these illegal immigrant women who have been lured into destination countries for greener pastures but at the end caught in the web of trafficking. It calls for a multicultural legal and policy framework in place to protect and respect the diverse experiences and interest of migrant women cut in the web of illegal syndicate marriages.

On top of that, there is also the urgency for international treaties and policies to eliminate inequalities that disadvantage these immigrant women against their counterpart male customers, for instance by giving them equal rights and opportunities as they have been bought as wives. Stringent laws should be enacted to criminalize illegal brokerage as this will help eliminate syndicate marriages and subsequent human trafficking.

\section{Acknowledgement}

The authors wish to thank the Universiti Kebangsaan Malaysia for providing the research grant funding under Geran Penyelidik Muda GGPM-2018-021 and TAP UKM-Ko22384

\section{References}

Abdallah S. M. (2021), Number of Malaysians getting married in Thailand countries to drop. Available at https://www.nst.com.mynews/nation/2021/o11658391/number-malaysians-getting-married-thailandcountries-drop.

Abella, M. I. (2004). The role of recruiters in labour migration. In D. S. Massey \& J. E. Taylor (Eds.), International migration: Prospects and policies in a global market (pp. 201-211). Oxford: Oxford University Press.

Abubaker J. (2018), ICA burst large syndicate that arranged sham marriages with Vietnamese women. Available at https://www.channelnewsasia.com/news/Singapore/ica-burts-large-syndicate-sham-marriage-Vietnamesewomen-10446672.

Alexander, P., 1997. Feminism, sex workers, and human rights. In Whores and other feminists, ed. J. Nagle: 83-97. New York: Psychology Press.

Ali M. (2012) Socio-Economic Analysis of Homeless Population in Urban Areas a Case Study of Northern Ethiopia. International Journal of Scientific and Research Publications 2012; 2 (8): 1-8.

Ali M. (2014) Status of Homeless Population in Urban Ethiopia: A Case Study of Amhara Region. International Journal of Management and Social Sciences Research (IJMSSR, 3(1): 61-68.

Andrade R. Health and social well-being in chronically homeless women: Tucson and Southern Arizona's current risks and future opportunities. Making Action Possible in Southern Arizona (MAP Dashboard) 2018; White Paper \#8. www.mapazdashboard.arizona.edu. 
Balistreri K.S., Joyner K., Kao G., (2017). Trading Youth for Citizenship? The Spousal Age Gap in CrossBorder Marriages. Popul Dev Rev. 2017 September; 43(3): 443-466.

Bélanger, D. (2016). Beyond the brokers: Local marriage migration industries of rural Vietnam. positions: East Asia cultures critique, 24(1), 71-96.

Bélanger, D., \& Rahman, M. (2013). Migrating against all the odds: International labour migration of Bangladeshi women. Current Sociology, 61(3), 356-373. https://doi.org/10.1177/oo11392113484453

Bretherton Joanne and Pleace Nicholas. Women and rough sleeping: A critical review of current research and methodology. University of York, Centre for Housing Policy 2018. P-15, 19. https://www. york.ac.uk/chp/

Celikaksoy, A., Nielsen, H. and Verner, M. (2006). Marriage migration: just another case of positive assortative matching? Review of Economics of the Household, 4, 271-293.

Charsley, K. (2013). Transnational Pakistani Connections: Marrying 'Back Home'. New York/London: Routledge.

Chee, H. L. (2012). From client to catchmaker: Social capital in the caking of commercial matchmaking agents in Malaysia. Pacific Affairs, 85(1), 91-115. doi:10.5509/201285191.

Choi Y., Kim D. \& Ryu J., (2019): Marital dissolution of transnational couples in South Korea, Journal of Ethnic and Migration Studies, DOI: 10.1080/1369183X.2019.1585021.

Chun C. S. Y. (1996) The Mail-ordered bride industry: the perpetuation of transnational economic inequalities and stereotypes. U. Pa. J. Int'l Econ. L. 17(4):1155-1208.

Constable, N. (2012). International marriage Brokers, cross-border marriages and the US anti-trafficking campaign. Journal of Ethnic and Migration Studies, 38(7), 1137-1154. doi:10.108o/1369183X.2012.681457.

Constable, N. Romance on a Global Stage: Pen Pals, Virtual Ethnography, and Mail Order Marriages. Berkeley, CA: University of California Press; 2003.

Constable, N., 2005. Cross-border Marriages: Gender and Mobility in Transnational Asia. Philadelphia; University of Pennsylvania Press.

Constable, N., 2012. International marriage brokers, cross-border marriages and the US anti-trafficking campaign. Journal of ethnic and migration studies, 38(7): 1137-54.

Constable, N., ed. 2005. Cross-border Marriages: Gender and Mobility in Transnational Asia. Philadelphia: University of Pennsylvania Press.

Cranston, S., Schapendonk, J., \& Spaan, E. (2018). New directions in exploring the migration industries: Introduction to special issue. Journal of Ethnic and Migration Studies, 44(4), 543-557. doi:10.1080/1369183X.2017.1315504.

De Hart B., (2017), The Europeanization of Love. The Marriage of Convenience in European Migration Law. European Journal of Migration and Law 19 (2017) 281-306.

Duchesne A. Women and Homelessness in Canada: A brief review of the literature. OBM-McGill Center for Research on Children and Families 2015.

Edwards B., Guy-Walls P., Jacinto G. \& Robert F. Findings of a Study Exploring Homeless Street Females in Addis Ababa, Ethiopia: A Need for Community Based Programs International Journal of Gender and Women's Studies 2015; 3(1): 42-50. https://doi.org/10.15640/ ijgws.v3n1p6.

Eerbeek P. V., (2019) Thai local brokers in the Swedish berry industry: Roles and positions across time and space. At www.diva-portal.se/smash/get/diva2:1329322/FULLTEXTo1.pdf.

Elwert A. Opposites attract: Evidence of status exchange in ethnic intermarriages in Sweden. Lund Papers in Economic History, Population Economics. 2016:147. doi:10.1111/padr.12072.

Ersanilli E., and Charsley K., (2019) A Good Match? Education, Labour Market Position, and British South Asian Transnational Marriage. European Sociological Review, 2019, Vol. 35, No. 1, 133-146 doi: 10.1093/esr/jcyo40.

Faist, T. (2014). Brokerage in cross-border mobility: Social mechanisms and the (re)production of social inequalities. Social Inclusion, 2(4), 38-52. doi:10.17645/si.v2i4.29.

Freeman, C., 2011. Making and faking kinship: Marriage and labor migration between China and South Korea. Cornell University Press.

Gammeltoft-Hansen, T., \& Nyberg Sørensen, N. (Eds.). (2013). The migration industry and the commercialization of international migration. London: Routledge.

Graycar A., (2000) "Human smuggling” unpublished paper, Australian Institute of Criminology, Canberra.

Guetto R, Azzolini D. An empirical study of status exchange through migrant/native marriages in Italy. Journal of Ethnic and Migration Studies. 2015; 41(13):2149-2172.

Hamel, C. et al. (2012). Union formation and partner choice. In Crul M., Schneider J. and Lelie F. (Eds.), The European Second Generation Compared. Does the Integration Context Matter? Amsterdam: Amsterdam University Press.

Hak, A.N., Said, M.H., Hashim, N., Soh, C.R.(2017), Cross-border marriages: Socio-legal knowledge among Muslims in Malaysia Pertanika Journal of Social Sciences and Humanities, 2017, 25(October), pp. 135-144 
Hoang TL, K Carrington, TH Tran, TP Nguyen, TK Le and NH Bui (2018) Inter-agency cooperation to raise awareness on human trafficking in Vietnam: Good practices and challenges. Asian Journal of Criminology 13: 251-274. https://doi.org/10.1007/s11417-018-9269-X

Hughes, D. M., 200o. The "Natasha" Trade: The Transnational Shadow Market of Trafficking in Women. Journal of International Affairs, 53(2): 625-51.

Hughes, D.M., 2004. 'The Role of Marriage Agencies in Sexual Exploitation and Trafficking of Women from the Former Soviet Union.' International Review of Victimology.11: 49-71.

Hwang M and Parrenas R (2018) Intimate migrations: The case of marriage migrants and sex workers in Asia. In Liu-Farrer G and Yeoh B (eds) Routledge Handbook of Asian Migrations: 64-74. New York: Routledge.

Ibrahim I. N. (2018), Immigration: Syndicate marrying off foreign women to elderly locals for sex work. Available. At https://www.malaysiamail.com/news/malaysia/2018/10/27/immigration-syndicate-marrying-off-foreignwomwn-to-elderly-locals-for-sex/1687175.

Icduygu A. and Toktas S., (2002) "How do smuggling and trafficking operate via irregular border crossings in the Middle East? Evidence from Fieldwork in Turkey" International Migration, 40(6):25-54.

IOM (International Organization for Migration), (2000) Myths and realities of Chinese Irregular Migration, IOM, Geneva.

Jamaluddin, Faisal, Manfarisyah, Hashim, F. Y. ., \& M.Said, M. H.(2021). Proposed Improvement for Divorce Resolution in Aceh And Malaysia: A Comparative Study. Academic Journal of Interdisciplinary Studies, 1o(1), 193. https://doi.org/10.36941/ajis-2021-0017

Kapur S., Zajicek A.M., and Gaber J., (2015). Non-profit Organizations Serving Domestic Violence Survivors: Addressing Intersectional Needs of Asian Indians. Affilia: Journal of Women and Social Work 1-17. DOI: 10.1177/0886109915592669.

Kapur S.and Zajicek A., (2018). Constructions of Battered Asian Indian Marriage Migrants: The Narratives of Domestic Violence Advocates. Violence Against Women 1-21. DOI: 10.1177/1077801218757373.

Kawaguchi D. and Lee S., (2016). Brides for sale: cross-border marriages and female immigration. Western Economic Association International. doi:10.1111/ecin.12411

Kay Patterson AO, Kathryn Proft and Joanna Maxwell. Older Women's Risk of Homelessness: Background Paper. Australian Human Rights Commission 2019. P- 14. www.humanrights.gov.au/about/ publications.

Ketema, N. (2014). Female Ethiopian migrant domestic workers: An analysis of migration, return-migration and reintegration experiences (Unpublished master's thesis). University of Oregon Graduate School, Eugene.

Kifleyesus, A. (2012). Women who migrate, men who wait: Eritrean labor migration to the Arab near east. Northeast African Studies, 12(1), 95-127. https://doi. org/10.1353/nas.2012.0028.

Kim H.M., Park S. \& Shukhertei A., (2017) Returning home: marriage migrants' legal precarity and the experience of divorce, Critical Asian Studies, 49:1, 38-53, DOI: 10.1080/14672715.2016.1266679.

King, R. (2012). Geography and migration studies: Retrospect and prospect. Population, Space and Place, 18(2), 134-153. doi:10.1002/psp.685.

Kook k., (2019) North Korean Escapees' Unthinkable Journeys and the Conceptual Binaries of Migration Policy. Electronic thesis or dissertation has been downloaded from Explore Bristol Research, http://researchinformation.bristol.ac.uk

Kook, K., 2018. "I Want to Be Trafficked so I Can Migrate!”: Cross-Border Movement of North Koreans into China through Brokerage and Smuggling Networks. Annals of the American Academy of Political and Social Science. 676: 114-34.

Korea Immigration Service Statistics 2014 Statistic Annual Report. http://www.immigration.go.kr Lan, P.-C.

Kuptsch, C. (Ed.) (2006). Merchants of labour. Geneva: International Labour Organization.

Levin Rebekah, Mckean Lise, Raphael Jody. Pathways to and from homelessness: Women and children in Chicago shelters. Homeless families 2004. www.impactresearch.org.

Lin J. (2018) 'Assisting you to become a local': NGOs and constructed foreign spouses in Eastern Taiwan, Gender, Place \& Culture, 25:1, 118-133, DOI: 10.1080/o966369X.2017.1395819.

Lin, W., Lindquist, J., Xiang, B., \& Yeoh, B. S. A. (2017). Migration infrastructures and the production of migrant mobilities. Mobilities, 12(2), 167-174. doi:10.108o/17450101.2017.1292770.

Lindquist, J. (2012). The elementary school teacher, the thug and his grandmother: Informal brokers and transnational migration from Indonesia. Pacific Affairs, 85(1), 69-89. doi:10.5509/201285169.

Lindquist, J., B. Xiang, and B. S. A. Yeoh. 2012. “Opening the Black Box of Migration: Brokers, the Organization of Transnational Mobility and the Changing Political Economy in Asia.” Pacific Affairs 85 (1): 7-19

Lindquist, J., Xiang, B., \& Yeoh, B. S. A. (2012). Opening the black box of migration: Brokers, the organization of transnational mobility and the changing political economy in Asia. Pacific Affairs, 85(1), 7-19. doi:10.5509/20128517. 
Lu, M. Commercially arranged marriage migration: Case studies of cross-border marriages in Taiwan. In: Palriwala, R., Uberoi, P., editors. Marriage, Migration and Gender. London: Sage; 2008. p. 125-151.

Luhmann, N. 1993. Risk: A Sociological Theory. New York: Walter de Gruyter

Luong HT (2020) Transnational crime and its trends in South-East Asia: A detailed narrative in Vietnam. International Journal for Crime, Justice and Social Democracy 9(2): 88-101. https://doi.org/10.5204/ijcjsd.v9i2.1147.

Mackellar M. (2008), Illegal Immigration from Asia: An examination of methods used to circumvent Australia's controlled visa system. Thesis submitted at Charles Darwin's University Darwin, Australia. Available at https://ris.cdu.edu.au/ws/portalfiles/portal/22705186/Thesis_CDU_8312_Mackellar_M.pdf.

Martin, P. (2017). Merchants of labor: Recruiters and international labor migration. Oxford: Oxford University Press.

Mayock P. and Sheridan S. (2012) Women's 'Journeys' to Homelessness: Key Findings from a Biographical Study of Homeless Women in Ireland. Women and Homelessness in Ireland, Research Paper 1, P-o1. Dublin: School of Social Work and Social Policy and Children's Research Centre, Trinity College Dublin.

McKeown, A. (2012). How the box became black: Brokers and the creation of the free migrant. Pacific Affairs, 85(1), 21-45. doi:10.5509/201285121.

McKeown, A. 2012. "How the Box Became Black: Brokers and the Creation of the Free Migrant." Pacific Affairs 85 (1): $21-45$.

MPS (2018) Annual Report for Trafficking in Persons. Hanoi, Vietnam: National Plan Committee against Trafficking in Persons [Vietnamese language].

Nathan M.A. and Fratkin E. (2018). The Lives of Street Women and Children in Hawassa, Ethiopia. African Studies Review; 61(1): 158-184. https://doi.org/10.1017/asr.2017.135.

Nhien CP (2016) Preventing and Combating Women Trafficking from Vietnam to China. Newcastle, UK: University of Northumbria.

Nisrane B. L., Ossewaarde R., and Need A., (2020). "I Should Get Married as Soon as Possible, but the Relationships I Start Do Not Work": Marital Prospects of Ethiopian Female Return Migrants from the Arabian Gulf. Journal of Family Issues oo(o):1-22. DOI: 10.1177/0192513X20948919.

Phuong TTH (2015) Protection for trafficked persons in Viet Nam: Another national security discourse. International Migration 53: 25-36. https://doi.org/10.1111/imig.12189.

Robinson-Pant, A., \& Magyar, A. (2018). The recruitment agent in internationalized higher education: Commercial broker and cultural Mediator. Journal of Studies in International Education, 22(3), $225-241$. doi:10.1177/1028315318762485.

Rodriguez, R. M. (2010). Migrants for export: How the Philippine state brokers labor to the world.

Salt J. (2000) “Trafficking and human smuggling: A European perspective from Asia” International Migration, 38(3):31-56

Said, M.H.M., Hashim, N.M., Hak, N.A., Wok, S., Soh, R.C. (2019), Socio-legal implications of cross-border marriage among Muslims in Malaysia: An empirical study. Al-Shajarah, 24(1), pp. 67-96

Salt, J., \& Stein, J. (1997). Migration as a business: The case of trafficking. International Migration, 35(4), 467-494.

Salidon R., Kamaruddin Z., Adil M. A. M., Arifin M., Ibrahim M. (2015). Review of illegal marriages: A maqasid Al Sharia perspective. In international conference on Maqasid Al-Shariah in public policy \& guidance, $15^{\text {th, }}$ and $16^{\text {th }}$ June 2015. International institute of advanced Islamic studies.

Schaeffer, FA. Love and Empire: Cybermarriage and Citizenship across the Americas. NYU Press; 2013.

Shelley L., (2001) "Trafficking and smuggling in human beings", paper presented at the George C. Marshall European Center for Security Forces Conference on Corruption within Security Forces: Organized Crime as a Threat to National Security, 14 - 18 May, Garmisch.

Skeldon R., (2000) “Trafficking: A perspective from Asia” international Migration, 38(3):7-30.

Skeldon, R. (2015). Temporary, seasonal, circular migration. In A. Triandafyllidou (Ed.), Routledge Handbook of Immigration and Refugee Studies (pp. 104-109). London: Routledge.

Smith S.A., (2019) Gender, Relationships and Sexual Violence in the Lives of Women from Chuuk, Micronesia, Journal of Aggression, Maltreatment \& Trauma, 28:2, 146-165, DOI: 10.1080/10926771.2018.149423.

Stovel, K., \& Shaw, L. (2012). Brokerage. Annual Review of Sociology, 38(1), 139-158. Retrieved from https://doi.org/10.1146/annurev-soc-o81309-150054. doi:10.1146/annurev-soc-081309-150054.

Straiton M.L., Ansnes T.J. and Tschirhart N., (2019), Transnational marriages and the health and well-being of Thai migrant women living in Norway. International Journal of Migration, Health and Social Care 15(1): 107 119. DOI 10.1108/IJMHSC-01-2018-0002.

Tailby R., (2001) “Organized crime and people smuggling/trafficking to Australia”, paper in trends and issues in crime and criminal justice, Australian Institute of Criminology, Canberra. 
Thomas C.M. Women and Homelessness: Understanding Risk Factors and Strategies for Recovery. Preble Street Reports 2009. www.preblestreet.org..

Tracy Flaherty-Willmott. Women's experiences of housing instability \& homelessness in St. ThomasElgin. Literature review and community survey results. YWCA 2019. P-1

Tsay, C.L., 2004. Marriage migration of women from China and Southeast Asia to Taiwan. G.W. Jones and K. Ramdas (eds.): 173-91.

Ullah, A. A. (2013). Mother's land and others' land: "Stolen" youth of returned female migrants. Gender, Technology and Development, 17(2), 159-178.

Wang, H., and Chang, S., 2009. The Commodification of International Marriages: Cross-Border Marriage Business in Taiwan and Viet Nam. In H. Wang and Xiao (eds.). Cross Border Marriages with Asian Characteristics. Taipei, Taiwan: Academia Sinica, Centre for Asia-Pacific Area Studies: 1-2.

Wemyss G., Yuval-Davis N and Cassidy K., (2018) 'Beauty and the Beast': Sham Marriage and Everyday Bordering Discourse. Political Geography, 66. pp. 151-16o. $\quad$ ISSN $0962-\quad 6298$. https://doi.org/10.1016/j.polgeo.2017.05.008.

Williams, L., 2010. Global Marriage: Cross-border Marriage Migration in Global Context., London: Palgrave Macmillan.

Wray, H.E., 'The "pure” relationship, sham marriages and immigration control', in: J. Miles, R. Probert \& P. Mody (eds), Marriage Rites and Rights (Hart Publishing, Oxford, 2015), pp. 141-165. Xiang, B., \& Lindquist, J. (2014). Migration Infrastructure. International migration review, 48(Supp.1), S122-S148. doi:10.1111/imre.12141.

Yeoh B.S.A., Chee H.L. \& Baey G. (2017): Managing risk, making a match: brokers and the management of mobility in international marriage, Mobilities, DOI: 10.1080/17450101.2017.1292779.

Yu S. and Chen F. (2018), Life Satisfaction of Cross-Border Marriage Migrants in South Korea: Exploring the Social Network Effects. IMR 52(2):597-634 597. DOI: 10.1111/imre.12287. 